\title{
Remaining Foreign Fighters: Fear, Misconceptions and Counterproductive Responses
}

\author{
Yrsa Landström
}

\begin{abstract}
The Syrian conflict gave rise to a large mobilization of Islamist foreign fighters. In recent years, many of these foreign fighters have asked to be repatriated from overcrowded refugee camps in northern Syria, camps known as hotbeds for radicalization. While researchers and humanitarian organizations largely agree that repatriation can prevent further radicalization and transnational threats, political leaders refuse to act. As the dire humanitarian situation in the camps and a denial of responsibility at home intensify, the situation is becoming more acute. This chapter explores the issue of remaining foreign fighters in Syria and the evolving threat situation as an example of a creeping crisis. The chapter focuses specifically on the Swedish handling of these foreign fighters. At least three hundred Swedish citizens traveled to Syria in 2012. In recent years, many of these have asked to be repatriated. Similar to its European counterparts, the Swedish government has refused to meet
\end{abstract}

\footnotetext{
Y. Landström $(\bowtie)$

Department of Security, Strategy and Leadership, Swedish Defence University, Stockholm, Sweden e-mail: Yrsa.Landstrom@fhs.se
}

(C) The Author(s) 2021

A. Boin et al. (eds.), Understanding the Creeping Crisis, https://doi.org/10.1007/978-3-030-70692-0_4 
these foreign fighters' requests, potentially generating a broader global threat. The Swedish response is the focus of this chapter and illuminates one of the key aspects of a creeping crisis.

Keywords Creeping crisis $\bullet$ Terrorism $\bullet$ Foreign fighters $\bullet$ Swedish government $\bullet$ Radicalization

\subsection{INTRODUCTION}

Osama bin Laden, stripped of his Saudi passport, is Exhibit A of the potential risk of assuming that problematic citizens barred from return will remain someone else's problem. (Malet \& Hayes, 2020, p. 1624)

Foreign fighters, also known as transnational insurgents or noncitizens who join insurgencies in civil conflicts, are not a new phenomenon (Malet, 2013 , p. 9). Indeed, foreign fighters have participated in "nearly 100 civil wars over the past 250 years" (UN Office on Drugs and Crime, 2019, p. 3). However, it was not until the Syrian conflict began in 2011 that political leaders and policymakers paid serious attention to them. The Syrian conflict has attracted one of the largest mobilizations of Islamist foreign fighters to date, with a substantial number arriving from Europe. Many European foreign fighters have requested to be repatriated from overcrowded custodial and refugee camps in northern Syria, camps known as hotbeds for radicalization (European Parliamentary Research Service, 2018; Pokalova, 2020).

Their participation in terrorist groups has caused widespread fear in their respective home countries, ostensibly because of the risk of terrorist attacks once they return. Politicians in many countries, therefore, have barred them from returning home. Such measures are put in place as a perceived response to a security threat, but experts warn the issue is more complicated than that. Malet and Hayes $(2020$, p. 1628) argue that while barring remaining foreign fighters "from re-entry may remove immediate potential domestic threats, the approach carries the risk of creating transnational threats when stateless individuals turn to extremist networks and failed states for refuge" (see also Alimi, Demetriou, \& Bosi, 2015; Bjørgo, 2016; Brandon, 2009; Crenshaw, 1981; Della Porta, 2018; Horgan \& Bjorgo, 2009; Horgan, 2014; Toros, 2008; Malet, 2013; Neumann, 2010; Weisburd et al., 2017). Such warnings, however, have not deterred 
European political leaders and policymakers from refusing to repatriate remaining foreign fighters in Syria, for instance.

This chapter explores the perceived threat of remaining foreign fighters in Syria as an example of a "creeping crisis," defined in the introductory chapter of this volume. The chapter focuses specifically on the Swedish handling of these foreign fighters. At least three hundred Swedish citizens traveled to Syria in 2012. In recent years, many of these have asked to come home. Similar to other European countries, the Swedish government has refused to meet these requests. Although precursor events, in the form of terrorist activity at home and in the camps, have caught the attention of governmental actors, effective action to counter the risks and threats associated with leaving these foreign fighters in Syria is largely absent.

To fully understand the dynamics of this case, in which foreign fighters are stuck in dire humanitarian camps in Syria and governments deny responsibility for these individuals, the creeping crisis concept is useful. The concept captures the "slow-burning" dimension of this situation, and highlights one aspect in particular: governing elites have generated not only an insufficient response but a counterproductive one. By responding to one perceived crisis in a particular way, they generate the contours of another. These response dynamics are thus the focus of this chapter and illuminate a key aspect of a creeping crisis: how a sufficient response depends on a consensus on how precursor events and effective measures are to be interpreted. The creeping crisis of remaining foreign fighters is in plain sight, but policymakers do little to resolve it and thereby plant the seed for an arguably more serious crisis later.

The chapter is divided into four sections. It starts by introducing the evolution of the problem over time and space as well as precursor events, recapitulating the situation, and outlining previous research. It then discusses the varying degrees of attention and action, analyzing Swedish political and societal responses before critically discussing it in light of other countries' actions. The final section reflects on the findings, explores possible reasons for the counterproductive response, and sets out future research questions.

\subsection{The Evolution of the Problem}

In the Spring of 2011, uprisings against authoritarian regimes were spreading in the Middle East. These uprisings, collectively known as the Arab Spring, involved anti-government and pro-democracy protests and 
armed clashes. This was also the case in Syria, where protesters challenged the regime of Bashar al-Assad. When security forces opened fire in Syria, more people joined the protests and violence escalated quickly (Pokalova, 2020 , p. 39). Soon after, individuals sympathetic to the various causes began traveling to Syria to join all sides of the conflict: pro-Assad forces, opposition forces, as well as groups with sectarian Islamist overtones. Since 2012, at least three hundred of these "foreign fighters" have left Sweden for Syria (Swedish Security Service, 2017).

Over time, Islamist groups, especially Daesh, ${ }^{1}$ attracted the majority of foreign fighters. Over a few years, the numbers reached up to forty thousand, one of the biggest mobilizations of Islamist foreign fighters to date (Pokalova, 2020, p. 40). In 2013, and again in the beginning of 2015, the numbers skyrocketed following Daesh's declaration of a "Caliphate" (UN Secretary-General, 2015). Although it appears that foreign fighters travel with the sole purpose of fighting in battle, this was not the case in Syria. A large number came with families and friends to stay and live in the conflict zones (Pokalova, 2020, p. 52).

European officials forecasted the return of many foreign fighters from Syria after 2012. These statements were later revised when this influx did not seem to occur (European Parliamentary Research Service, 2018, p. 31). One notable reason for this was the capture of Daesh fighters in northern Syria by Kurdish-led militias, which was made possible with US military support. That support ended in December 2018 when US President Trump declared that two thousand US troops would be extricated from Syria (Chulov, Borger, \& Roth, 2018). With the US withdrawal, Turkey began to intervene militarily across the border and, more specifically, into Kurdish-held areas. Kurdish militias experienced difficulties holding foreign fighters with the little resources they had, complicated by the Turkish military forcing them to leave (Savage, 2019; UN Security Council Committee, 2020, p. 25).

As the Syrian conflict evolved, many foreign fighters started calling for help from European authorities to be brought back home. Due to the terrible conditions in refugee and custodial camps held by Kurdish militias, Swedish foreign fighters called on Swedish authorities to be repatriated. These included Swedes held in the overcrowded camp in al-Hawl, a camp known for holding many Daesh women and children. It has been estimated that over two-thirds of the seventy thousand in the al-Hawl camp are

\footnotetext{
${ }^{1}$ Also known as ISIL, IS or the Islamic State.
} 
children (International Committee of the Red Cross, 2019). Female combatants and child indoctrination are characteristic of Daesh. There have been reports about women imposing Daesh rules inside prisons and conducting executions of prisoners inside camps. Other reports warned about the rise of new generations inculcated with Daesh ideologies, describing how children participated in military training. These processes point to an evolving threat situation where al-Hawl and other camps in northern Syria have become a hotbed for (further) radicalization (European Parliamentary Research Service, 2018; Cafarella, 2018; Benotman \& Malik, 2016).

Meanwhile, in Syria and Iraq, Daesh affiliates continued to mount "increasingly bold insurgent attacks, calling and planning for the breakout of ISIL fighters in detention facilities and exploiting weaknesses in the security environment of both countries" (UN Security Council Committee, 2020 , p. 3). Reports describe money transfers to Daesh, too (UN Security Council Committee, 2020, pp. 17-18; Baas, 2020). Many of these transfers not only go to Daesh in Syria and Iraq, but to widows and orphans of deceased fighters. This money strengthens the organization, helps to ensure loyalty, and builds support for generations to come (UN Security Council Committee, 2020, pp. 17-18).

\subsubsection{Precursor Events}

The threat at the heart of this creeping crisis is complex and well known. Child indoctrination, further radicalization in custodial and refugee camps, money transfers and recruits of new affiliates: remaining foreign fighters are a serious security problem facing the world.

Political leaders have taken a particular stance on the problem. Measures were introduced based on the assumption that foreign fighters "would be skilled terrorists and that roughly ten percent of them would commit domestic attacks" (Malet \& Hayes, 2020, p. 1621). In 2014, a French foreign fighter killed four people at the Jewish Museum in Brussels. The attacker, Mehdi Nemmouche, had recently returned from Syria where he spent one year fighting for Daesh (Lister, 2015, p. 2). In November 2015, several attacks took place in Paris, leaving one hundred thirty people dead and hundreds wounded. The individuals arrested were connected to networks including Daesh foreign fighters $(B B C, 2016$; Entenmann, Van der Heide, Weggemans, \& Dorsey, 2015, p. 4). Only a few months later, in March 2016, Brussels experienced three suicide bombings. Casualties 
included thirty-two dead and more than seven hundred wounded. The attackers were foreign fighters or engaged in networks with foreign fighters (Lasoen, 2017, pp. 940-941). These attacks were used as the basis for harsh penalties against potential terrorists (Malet \& Hayes, 2020, p. 1621). Such penalties included, not least, a refusal to repatriate foreign fighters in Kurdish-held camps in Syria.

Historically, responses to foreign fighters have varied from repressive to more humane. Researchers across disciplines studied different approaches and their outcomes. There appears to be a scholarly consensus on the counterproductive effects of repressive measures (e.g., Alimi et al., 2015; Bjørgo, 2016; Brandon, 2009; Crenshaw, 1981; Della Porta, 2018; Horgan \& Bjorgo, 2009; Horgan, 2014; Toros, 2008; Malet, 2013; Neumann, 2010; Weisburd et al., 2017). Preventing foreign fighters from returning home displaces the problem to another (less equipped) country and turns foreign fighters into stateless people and/or generates a transnational threat (Dechesne, 2011; Malet \& Hayes, 2020; Lister, 2015). In addition, scholars have noted that social settings where extremist thought and behavior are present tend to increase the potential for radicalization (Alimi \& Demetriou, 2018, pp. 559-560). Indeed, radicalization by its very nature is a "process whereby individuals or groups come to embrace violence as a legitimate means to achieve political, ideological or religious goals" (Bjørgo, 2016, p. 27).

For this reason, countering and preventing this threat is "to a great degree a normative battle on whether the use of violence is legitimate or not" (Bjørgo, 2016, p. 27). Much of the research points not only to the counterproductive effects of repressive measures but to the longer-term benefits of humane "soft" responses. Toros demonstrates how a humane approach "may offer a path of empowerment for the norm of nonviolent political contestation" (Toros, 2008, p. 423), Marsden concludes in her work on reintegration of extremists that for countermeasures to work "society must allow, and ideally actively support, the individual's reintegration" (Marsden, 2017, p. 11).

In short, repressive measures, including a refusal to repatriate remaining foreign fighters, may appear politically attractive in the short term but tend to push these individuals to engage in (additional) violence (Malet \& Hayes, 2020, p. 1624). Nevertheless, political leaders, including the Swedish government, continue to prevent foreign fighters from returning to their home countries. 


\subsection{A Varying Degree of Attention and Action}

The problem of remaining foreign fighters has not gone unnoticed. The Swedish government, its agencies, media, civil society, and international institutions have raised the issue in various ways but with no overarching consensus as to what is at stake.

\subsubsection{The Swedish Government}

Since 2016, the Swedish government has introduced new laws to counter the issue of remaining foreign fighters, including laws against traveling with the intention to fight in a conflict zone, against the financing of terrorism activities, and to prevent individuals from associating with a terrorist organization (Swedish Parliament, 2017; Swedish Parliament, 2020). In early 2019, Swedish ministers argued that an international tribunal in Syria, to dole out "harsher punishments," should be established (Damberg \& Johansson, 2019; SVT, 2019a). They refused to repatriate Swedish foreign fighters from Syrian camps, including their children, stating that "the family has the responsibility for their children [not us]" (Damberg \& Johansson, 2019).

In April 2019, the Swedish government announced that rather than bringing these individuals back to Sweden, it had earmarked two million Swedish crowns to support refugee camps in Syria (SVT, 2019b). This shift of responsibility was noted by Save the Children (2019), when it published a letter to the Swedish Prime Minister criticizing the Swedish handling of remaining foreign fighters' children. That same day, the Minister for Foreign Affairs announced that "there should be no doubt that the government is doing what we can for these children and, if possible, they should be brought back home" (Wallström, 2019). Yet in October 2019, the Swedish Prime Minister demonstrated the government's continued resentment toward repatriation, stating that "I can only feel disgusted [of the remaining foreign fighters]" and "those who went there, they should pay the price [stå sitt kast]" (Orrenius, 2019a). As of October 2020, the Swedish stance on adult foreign fighters had not changed. 


\subsubsection{Swedish Media}

Media has an important role in legitimizing state action via its reporting on terrorism, signaling approval of some actions and "othering" individuals associated with terrorism (Mueller, 2005). In this case, Swedish media, especially publicly funded media, have taken on a delegitimizing role, producing critical pieces toward the government's measures and giving a voice to remaining foreign fighters. Interestingly, Swedish media tend to describe remaining foreign fighters, especially women and children, as victims, in contrast to government statements. For instance, several Swedish media outlets have closely followed the grandfather of a foreign fighter and his journey to retrieve his grandchildren from Syria, with headlines such as “Grandfather to Skråmo's children: I started to cry" (Sveriges Radio, 2019b) and "Patricio Galvez's seven grandchildren found in Syria-this is the picture of the reunion" $(S V T, 2019 \mathrm{c})$.

\subsubsection{Civil Society}

Representatives of civil society, in Sweden as well as abroad, have pushed the Swedish government to repatriate remaining foreign fighters, especially women and children. In 2019, a Kurdish delegation visited the Swedish government to urge the return of Swedish citizens from northern Syria (Save the Children, 2019). Humanitarian organizations, such as Save the Children, Doctors without Borders and The Red Cross, have provided alarming accounts of the dire humanitarian situation in northern Syria. They criticized the lack of responsibility displayed by European countries, highlighting the Swedish approach. Save the Children and The Red Cross have, for instance, described the Swedish approach as "completely unsustainable" (Göteborgs-Posten, 2020) and castigated the Swedish government for acting against the UN Convention on the Rights of the Child (Sveriges Radio, 2019a). The Director-General of the International Committee of The Red Cross chastised the Swedish government, stating: "you cannot continue to refrain from making decisions about your citizens" (Orrenius, 2020). Doctors without Borders emphasized that "everyone has the right to medical and humanitarian support, regardless of background, nationality, status or where they come from" (Doctors without Borders, 2019).

Some governmental agencies joined the chorus. For instance, the Swedish National Coordinator Against Violent Extremism argued that the 
Swedish government needs to take more responsibility on the matter (Sveriges Radio, 2015; Carlstedt, 2017). In 2019, the Swedish Security Service reported on Syrian camps nurturing "new generations of terrorists" and the Head of Analysis, Ahn-Za Hagström, suggested her disapproval of the Swedish approach, pointing out that "it is important to think carefully about how the measures that we as a society choose to address the threat in the long-term, for the next generation" and "we do things now that may seem good for the moment, but which may be threatening in the long-term" (Ahn-Za Hagström cited in Orrenius, 2019b).

\subsubsection{International Institutions and Other Countries' Responses}

Since 2014, international institutions have expressed their concern over remaining foreign fighters and emphasized their supportive role by providing resolutions and guidelines to member states. Some, like the International Centre for Counter Terrorism, in The Hague, have called for humane, soft approaches (Entenmann et al., 2015; Eurojust, 2015). Although the transnational nature of the problem is repeatedly discussed among these actors, multilateral institutions and agencies have simultaneously stated that the primary responsibility lies with member states (UN Security Council, Resolution 2178, 2014, p. 4; Entenmann et al., 2015, p. 5; Eurojust, 2015). There are some voices, such as the EU CounterTerrorism Coordinator, who have urged European institutions to take on a bigger role (Washington Institute, 2015).

Similar to its Swedish neighbors, Danish government officials deny they are responsible for remaining foreign fighters with Danish citizenship in Syria. The Danish Minister for Immigration argued against repatriation on the basis that these individuals have gone to fight against democracy, freedom and "everything else that Denmark stands for" (The Local, 2019). Moreover, the Minister stated that these foreign fighters and their children "do not belong in Denmark" and "have turned their back on Denmark, so there is no reason for their children to be citizens" (The Local, 2019). In 2019, Denmark introduced two new laws making it possible for the government to revoke passports without court procedures and revoke citizenship from children born "in areas where it is illegal to travel" (The Local, 2019).

Similarly, in 2015, Australia introduced a new law giving the Australian government the right to revoke Australian citizenship from "people who 
hold a second nationality if they are found to have been members of a terrorist group or engaged in terrorism-related activity" (Williams, 2017). In 2017, this law was put into practice for the first time when a foreign fighter still in Syria was stripped off his Australian citizenship. That same year, the UK government took away citizenship from 104 UK foreign fighters (with dual nationality), on the grounds that it would be "conducive to the public good" (Williams, 2017). In 2019, the US President told the State Department to ban the return of a US citizen who had left for Syria. Ironically, the President made this statement only a few days after he called on European leaders to bring back foreign fighters from Syria (Hincks, 2019).

The creeping crisis of remaining foreign fighters affects more than a few countries. Some governments have been forced to change their stance on repatriation, often due to legal constraints. For instance, in July 2019, a court ruling ordered German authorities to repatriate a German woman and her three children from northern Syria. A spokesperson for the German foreign ministry explained soon after the ruling that the government was "studying the ruling and may appeal at a higher court" ( $A l$ Jazeera, 2019).

Similarly, French authorities faced a lawsuit at the European Court of Human Rights over its refusal to repatriate children from Syria. The lawyer of this lawsuit, representing the French grandparents of a daughter and her two children detained in Syria, argued in a television interview in 2019 that, "this approach aims to push the state to assume its responsibilities because we are confronting inaction; more precisely, an irresponsible and particularly inhumane inertia" (France 24, 2019a). A month after the lawsuit was announced, French authorities repatriated twelve French orphans from Syria (France 24, 2019b).

Some governments have successfully appealed lawsuits. In the Netherlands, the lawyers of twenty-three women with Dutch citizenship detained in Syria had argued in front of the court in The Hague to "force [obligation of result] the state to repatriate them and their 56 children" (France 24, 2019b). The Dutch government immediately appealed the verdict, arguing that the court had failed to account for "national security interests and diplomatic considerations" (France 24, 2019b). Soon after, the Court of Appeal overturned the ruling and concluded that Dutch authorities were, in fact, "not legally required to assist in the repatriation" (France 24, 2019b). 
At the time of writing, in November 2020, only a few European countries had repatriated their citizens without lawsuits or severe criticism involved. The Norwegian government is one example where the government, despite facing a political crisis (with the right-wing populist party threatening to leave the Norwegian government coalition, which they later did), decided to repatriate a foreign fighter and her two sick children (Holmgren, 2020a, 2020b).

\subsection{Conclusion}

How does the creeping crisis of remaining fighters continue, unabated? A key factor is the unwillingness of political decision-makers to deal with the problem. This chapter has documented a deep divide between civil society and political decision-makers with regard to their approach toward remaining foreign fighters. In short, representatives of civil society tend to argue for repatriation while political leaders tend to deny responsibility and push for harsher measures.

What explains the divide between the official approach and the expertled insight that this approach is likely counterproductive? One factor is the perceived relation with terrorism, a famously sensitive topic which tends to elicit fear and repressive measures (McConaghy, 2017). Political leaders tend to use firm measures as these are thought to demonstrate their ability to act in a rapid, resolute, and executive manner. Some parts of the Swedish media (along with some governments, such as Norway) argue for a more humane response. They propose a reaction that is informed by consideration of the foreign fighter as victims, what some call the victimization of foreign fighters (Sjoberg \& Gentry, 2011). By framing foreign fighters as victims, individual agency is downplayed and, as a result, the threat they pose. Yet most governments continue to resist that framing, refusing to act. As long as governments respond to the crisis of remaining foreign fighters as a threat at "home," they are likely to exacerbate the future, cross-border dimensions of the problem.

Indeed, this chapter illuminates one of the key aspects of a creeping crisis: how insufficient responses by authorities results in a continued and, in the case of counterproductive measures, acceleration of the threat and a greater risk of an acute crisis. The creeping crisis concept offers a heuristic to help deconstruct, analytically, the dynamics of this problem and some of this more troublesome (from a normative perspective) components. This chapter represents just a first set of answers and hypotheses that need 
to be tested in more systematic empirical ways. Future work should provide an in-depth analysis of feedback loops between threat evolution, attention, and response, and should examine what role short-term thinking might have for the evolving and increasing threat of radicalization. There is also a need for more thorough study of the transnational dimension of the phenomenon and associated questions of crisis ownership and responsibility. Future analysis of the issue of remaining foreign fighters can contribute much not only to our understanding of this particular global problem, but also to the utility and development of the creeping crisis concept itself.

\section{REFERENCES}

Al Jazeera. (2019, July 11). German court rules on repatriation of Syria ISIL fighter's family. Al Jazeera. Retrieved November 20, 2020, from https://www. aljazeera.com/news/2019/07/german-court-rules-repatriation-syria-isilfighter-family-190711164005146.html

Alimi, E. Y., \& Demetriou, C. (2018). Relational radicalization. In F. Dépelteau (Ed.), The Palgrave handbook of relational sociology (pp. 559-578). Cham: Palgrave Macmillan.

Alimi, E. Y., Demetriou, C., \& Bosi, L. (2015). Dynamics of radicalization: A relational and comparative perspective. Oxford: Oxford University Press.

Baas, D. (2020, February 3). IS-rekryteraren Ulrika Pape avslöjad. Expressen. Retrieved November 20, 2020, from https://www.expressen.se/nyheter/ har-avslojas-is-rekryteraren-ulrika-pape-av-expressens-dolda-kamera/

BBC. (2016, April 27). Paris attacks: Who were the attackers?. BBC News. Retrieved November 20, 2020, from https://www.bbc.com/news/ world-europe-34832512

Benotman, N., \& Malik, N. (2016). Children of the Islamic State. Quilliam. Retrieved November 20, 2020, from https://www.quilliaminternational. $\mathrm{com} /$ shop/e-publications/the-children-of-islamic-state/

Bjørgo, T. (2016). Counter-terrorism as crime prevention: A holistic approach. Behavioural sciences of terrorism and political aggression, 8(1), 25-44.

Brandon, J. (2009). The danger of prison radicalization in the West. CTC Sentinel, $2(12), 1-4$.

Cafarella, J. (2018, December 20). The Islamic State is not defeated. Trump must reverse his decision to withdraw from Syria. The Washington Post. Retrieved November 20, 2020, from https://www.washingtonpost.com/opinions/ $2018 / 12 / 20 /$ islamic-state-is-not-defeated-trump-must-reverse-his-decisionwithdraw-syria/ 
Carlstedt, A. (2017, March 27). Brister i arbetet med återvändare från terrorresor. Dagens Nyheter. Retrieved November 20, 2020, from https://www.dn.se/ debatt/brister-i-arbetet-med-atervandare-fran-terrorresor/

Chulov, M., Borger, J., \& Roth, A. (2018, December 20). US Syria pullout draws Kurdish condemnation and Putin's praise. The Guardian. Retrieved November 20, 2020, from https://www.theguardian.com/world/2018/dec/20/ syria-kurds-trump-troop-withdrawal-isis-turkey

Crenshaw, M. (1981). The causes of terrorism. Comparative Politics, 13(4), 389-399.

Damberg, M., \& Johansson M. (2019, March 11). Komplicerad situation for IS-återvändares barn. Dagens Nyheter. Retrieved November 20, 2020, from https://www.dn.se/debatt/komplicerad-situation-for-is-atervandares-barn/

Dechesne, M. (2011). Deradicalization: Not soft, but strategic. Crime Law and Social Change, 55(4), 287-292.

Della Porta, D. (2018). Radicalization: A relational perspective. Annual Review of Political Science, 21, 461-474.

Doctors without Borders. (2019). Syrien: stora oumbäranden bland kvinnor och barn $i$ al-Hol-lägret. Retrieved November 20, 2020, from https://lakareutangranser.se/nyheter/syrien-stora-umbaranden-bland-kvinnor-ochbarn-i-al-hol-lagret

Entenmann, E., Van der Heide, L., Weggemans, D., \& Dorsey, J. (2015). Rehabilitation for foreign fighters? Relevance, challenges and opportunities for the criminal justice sector. The International Centre for Counter-TerrorismThe Hague, 6(5), 27. https://doi.org/10.19165/2015.2.05

Eurojust. (2015). Foreign fighters: Eurojust's views on the phenomenon and the criminal justice response. Retrieved November 20, 2020, from http://www. statewatch.org/news/2015/feb/eu-eurojust-foreign-fighters.pdf

European Parliamentary Research Service. (2018). The return of foreign fighters to EU soil: Ex-post evaluation. Retrieved November 20, 2020, from https://www. europarl.europa.eu/RegData/etudes/STUD/2018/621811/ EPRS_STU(2018)621811_EN.pdf

France 24. (2019a, May 7). France taken to court for refusing to repatriate the children of jihadists. France 24. Retrieved November 20, 2020, from https:// www.france24.com/en/20190507-france-taken-court-over-repatriatingchildren-jihadists

France 24. (2019b, June 10). Syrian Kurds transfer 12 orphans form jihadist families to France for repatriation. France 24. Retrieved November 20, 2020, from https://www.france24.com/en/20190610-france-orphans-jihadistfamilies-syria-kurds-transfer

Göteborgs-Posten. (2020, February 7). Socialtjänsten: kan inte omhänderta barn i Syrien. Göteborgs-Posten. Retrieved November 20, 2020, from https://www. gp.se/nyheter/v\%C3\%A4rlden/socialtj\%C3\%A4nsten-kan-inte-omh\% C3\%A4nderta-barn-i-syrien-1.23657281 
Hincks, J. (2019, February 21). How ISIS returnees are stirring a debate over citizenship, security and rule of law. Time. Retrieved November 20, 2020, from https://time.com/5534674/shamima-begum-hoda-muthana-isis /

Holmgren, M. (2020a, January 16). Återvändande IS-kvinna bakom regeringskris i Norge. Dagens Nybeter. Retrieved November 20, 2020, from https:// www.dn.se/nyheter/varlden/atervandande-is-kvinna-bakomregeringskris-i-norge/

Holmgren, M. (2020b, January 18). IS-återvändarna känslig fråga i nordiska länderna. Dagens Nybeter. Retrieved November 20, 2020, from https://www. dn.se/nyheter/varlden/is-atervandarna-kanslig-fraga-i-nordiska-landerna/

Horgan, J. (2014). The psychology of terrorism. London and New York: Routledge.

Horgan, J., \& Bjorgo, T. (2009). Leaving terrorism behind: Individual and collective disengagement. London and New York: Routledge.

International Committee of the Red Cross. (2019). Syria: A camp is filled with children. Retrieved November 20, 2020, from https://www.icrc.org/en/document/Syria-A-camp-is-filled-with-children

Lasoen, K. L. (2017). Indications and warning in Belgium: Brussels is not Delphi. Journal of Strategic Studies, 40(7), 927-962.

Lister, C. (2015). Returning foreign fighters: Criminalization or reintegration?. Brookings Doha Center. Retrieved November 20, 2020, from https://www. brookings.edu/wp-content/uploads/2016/06/En-Fighters-Web.pdf

Malet, D. (2013). Foreign fighters: Transnational identity in civil conflicts. New York: Oxford University Press.

Malet, D., \& Hayes, R. (2020). Foreign fighter returnees: An indefinite threat? Terrorism and Political Violence, 32(8), 1617-1635. https://doi.org/10.108 0/09546553.2018.1497987

Marsden, S. (2017). Reintegrating extremists: Deradicalisation and resistance. London: Palgrave Macmillan.

McConaghy, K. (2017). Terrorism and the state: Intra-state dynamics and the response to non-state political violence. London: Palgrave Macmillan.

Mueller, J. E. (2005). Overblown: How politicians and the terrorism industry inflate national security threats, and why we believe them. New York: Free Press.

Neumann, P. R. (2010). Prisons and terrorism. Radicalisation and de-radicalisation in 15 countries. Policy Report. International Centre for the Study of Radicalisation and Political Violence (ICSR). https://www.clingendael.org/ sites/default/files/pdfs/Prisons-and-terrorism-15-countries.pdf.

Orrenius, N. (2019a, October 30). Statsministern blåser till strid mot antisemitismen- "Det är osvenskt". Dagens Nyheter. Retrieved November 20, 2020,fromhttps://www.dn.se/nyheter/sverige/statsministern-blaser-till-strid-motantisemitismen-det-ar-osvenskt/

Orrenius, N. (2019b, October 31). Säpo varnar för IS-lägren där svenska barn växer upp. Dagens Nyheter. Retrieved November 20, 2020, from https://www. dn.se/nyheter/sverige/sapo-varnar-for-is-lagren-dar-svenska-barn-vaxer-upp/ 
Orrenius, N. (2020, January 28). Röda korset-chefen: Sverige bör ta hem båda IS-kvinnor och deras barn. Dagens Nyheter. Retrieved November 20, 2020, from https://www.dn.se/nyheter/varlden/roda-korset-chefen-sverigebor-ta-hem-bade-is-kvinnor-och-deras-barn/

Pokalova, E. (2020). Returning Islamist foreign fighters: Threats and challenges to the West. London: Palgrave Macmillan.

Savage, C. (2019, October 13). The Kurds' prisons and detention camps for ISIS members, explained. The New York Times. Retrieved November 20, 2020, from https://www.nytimes.com/2019/10/13/us/politics/isis-prisonerskurds.html

Save the Children. (2019). Oppet brev till statsminister Stefan Löfven om barn $i$ Syrien. Retrieved November 20, 2020, from https://press.raddabarnen.se/ pressreleases/oeppet-brev-till-statsminister-stefan-loefven-om-barn-i-syrien2859904

Sjoberg, L., \& Gentry, C. E. (2011). Women, gender and terrorism. Athens and London: University of Georgia Press.

Sveriges Radio. (2015, February 8). IS och kommunernas brist på kunskap. Sveriges Radio. Retrieved November 20, 2020, from https://sverigesradio.se/ sida/avsnitt/496931

Sveriges Radio. (2019a, March 12). Sverige för samtal om IS-barnen. Sveriges Radio. Retrieved November 20, 2020, from https://sverigesradio.se/sida/ artikel.aspx?programid=83\&artikel=7198414

Sveriges Radio. (2019b, April 19). Morfar till Skråmos barn: jag började gråta. Sveriges Radio. Retrieved November 20, 2020, from https://sverigesradio.se/ sida/artikel.aspx?programid=83\&artikel $=7202692$

SVT. (2019a, February 24). Ministern: Familjerna ansvarar för sina barn. Sveriges Television SVT. Retrieved November 20, 2020, from https://www.svt.se/ nyheter/inrikes/ministerns-svar-de-har-ansvar-for-sina-barn

SVT. (2019b, April 9). Biståndsmiljoner öronmärks för barn till svenska IS-anhängare i Syrien. Sveriges Television SVT. Retrieved November 20, 2020, from https://www.svt.se/nyheter/utrikes/bistandsmiljoner-oronmarks-tillflyktinglager-i-syrien

SVT. (2019c, May 15). Patricio Galvez seven grandchildren found in Syria-this is the picture of the reunion. Sveriges Television SVT. https://www.svt.se/ nyheter/inrikes/nu-har-dode-is-terroristernas-barn-traffat-sin-svenska-morfar.

Swedish Parliament. (2017). Regeringens åtgärder kring återvändare som stridit för IS-Interprellation 2016/17:591 av Roger Haddad (L). Retrieved November 20, 2020, from https://www.riksdagen.se/sv/dokument-lagar/ dokument/interpellation/regeringens-atgarder-kring-atervandare-som_ H410591 
Swedish Parliament. (2020). Ett särskilt straffansvar för samröre med en terroristorganisation. Retrieved November 20, 2020, from https://www. riksdagen.se/sv/dokument-lagar/arende/betankande/ett-sarskilt-straffansvar-for-samroremed-en_H701JuU13

Swedish Security Service. (2017). Färre reser från Sverige till terroristorganisationer. Retrieved November 20, 2020, from https://www.sakerhetspolisen.se/ ovrigt/pressrum/aktuellt/aktuellt/2017-06-27-farre-reser-fran-sverige-tillterroristorganisationer.html

The Local. (2019, March 28). Danish government reaches agreement to revoke passports of Isis fighters. The Local. Retrieved November 20, 2020, from https://www.thelocal.dk/20190328/danish-government-reaches-agreementto-revoke-passports-of-isis-fighters

Toros, H. (2008). 'We don't negotiate with terrorists!': Legitimacy and complexity in terrorist conflicts. Security Dialogue, 39(4), 407-426.

UN Office on Drugs and Crime. (2019). Foreign terrorist fighters. Manual for judicial training institutes South-Eastern Europe. Retrieved November 20, 2020, from https://www.unodc.org/pdf/terrorism/Foreign_Terrorist_ Fighters_Handbook/EN_Foreign_Terrorist_Fighters_Ebook.pdf

UN Secretary-General. (2015). Secretary-General's remarks to Security Council meeting on threats to international peace and security caused by terrorist acts (foreign terrorist fighters). Retrieved November 20, 2020, from https://www. un.org/sg/en/content/sg/statement/2015-05-29/secretary-generals-remarkssecurity-council-meeting-threats

UN Security Council Committee. (2020). Letter dates 20 January 2020 from the Chair of the UN Security Council Committee pursuant to resolutions 1267 (1999), 1989 (2011) and 2253 (2015) concerning Islamic State in Iraq and the Levant (Da'esh), Al-Qaida and associated individuals, groups, undertakings and entities addressed to the President of the Security Council. S/2020/53. Retrieved November 20, 2020, from https://digitallibrary.un.org/ record/3848705

UN Security Council. Resolution 2178. (2014). S/RES/2178. Retrieved November 20, 2020, from https://www.un.org/sc/ctc/wp-content/ uploads/2015/06/SCR-2178_2014_EN.pdf

Wallström, M. (2019). Regeringen arbetar nu intensivt för att barn med koppling till Sverige som befinner sig i Syrien får den hjälp de behöver. Det ska inte råda något tvivel om att regeringen gör vad vi kan för dessa barn och om möjligt ska de föras till Sverige (...) [Post]. Facebook. https://www.facebook.com/margot.wallstrom/posts/2123875990994786

Washington Institute. (2015). Rehabilitation and Reintegration of Returning Foreign Terrorist Fighters. Retrieved November 20, 2020, from https://www. washingtoninstitute.org/policy-analysis/view/rehabilitation-andreintegration-of-returning-foreign-terrorist-fighters 
Weisburd, D., Farrington, D. P., Gill, C., Ajzenstadt, M., Bennet, T., Bowers, K., ... Wooditch, A. (2017). What works in crime prevention and rehabilitation: An assessment of systematic reviews. Criminology \& Public Policy, $16(2), 415-449$.

Williams, J. (2017, February 13). ISIS Fighter's Australian citizenship is revoked under antiterror laws. The New York Times. Retrieved November 20, 2020, from https://www.nytimes.com/2017/02/13/world/australia/citizenshipisis-khaled-sharrouf.html

Open Access This chapter is licensed under the terms of the Creative Commons Attribution 4.0 International License (http://creativecommons.org/licenses/ by $/ 4.0 /$ ), which permits use, sharing, adaptation, distribution and reproduction in any medium or format, as long as you give appropriate credit to the original author(s) and the source, provide a link to the Creative Commons licence and indicate if changes were made.

The images or other third party material in this chapter are included in the chapter's Creative Commons licence, unless indicated otherwise in a credit line to the material. If material is not included in the chapter's Creative Commons licence and your intended use is not permitted by statutory regulation or exceeds the permitted use, you will need to obtain permission directly from the copyright holder.

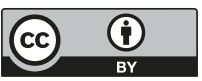

